\title{
Pseudomonas taeniospiralis sp. nov., an R-Body-Containing Hydrogen Bacterium
}

\author{
J. LALUCAT, ${ }^{1}$ R. PARÉS, ${ }^{1}$ AND H. G. SCHLEGEL ${ }^{2}$ \\ Departamento de Microbiología, Facultad de Biología, Universidad de Barcelona, Barcelona, Spain, ${ }^{1}$ and \\ Institut für Mikrobiologie der Universität Göttingen, Göttingen, Federal Republic of Germany ${ }^{2}$
}

Strain $2 \mathrm{~K} 1$ is the first free-living bacterium in which $\mathrm{R}$ bodies were detected. $\mathrm{R}$ bodies, previously known as kappa particles, consist of convoluted, proteinaceous ribbons and are typical and distinctive inclusions of cells of the genus Caedibacter Preer and Preer, obligately endosymbiotic bacteria of the Paramecium aurelia species complex. Strain $2 \mathrm{~K} 1$ is a yellow-pigmented, polarly flagellated, mesophilic, hydrogen-oxidizing bacterium. This facultatively chemolithoautotrophic organism can grow heterotrophically and is able to utilize a wide range of sugars; it can also grow heterotrophically as a denitrifying bacterium, but it does not fix nitrogen. Autotrophically grown cells contain a membrane-bound hydrogenase. Morphologically and biochemically, strain $2 \mathrm{~K} 1$ differs from other hydrogenoxidizing bacteria and from the known species of Caedibacter. This bacterium is considered to be a new species, for which the name Pseudomonas taeniospiralis is proposed. The specific epithet refers to the outstanding property of this organism, namely, that it contains $\mathrm{R}$ bodies (i.e., inclusion bodies consisting of convoluted proteinaceous ribbons). The type strain of $P$. taeniospiralis, strain $2 \mathrm{~K} 1$, has been deposited with the Deutsche Sammlung von Mikroorganismen as strain DSM 2082.

The killer trait in paramecia, which was first described by Sonneborn in 1936 (23), presents a major genetic and microbiological problem. Probably the best elucidated system is the system of the kappa particles. These particles, initially described as "plasmagenes" and subsequently described as parasitic bacteria, inhabit the cytoplasm of killer paramecia (22). 1 : bacterial nature of these particles is now well established (18). Kappa particles are obligate endosymbionts which cannot be cultivated outside their host protozoa. A distinct fraction of the kappa particle population contains a refractile inclusion body ( $\mathrm{R}$ body), whose function is thought to be release of a toxic substance into the cytoplasm of susceptible paramecia upon ingestion of the particles (18). The $\mathrm{R}$ body consists of a convoluted proteinaceous ribbon which is unique in nature. It is of taxonomic importance because it is the morphological characteristic which permits differentiation of kappa particles from other endosymbionts of the Paramecium aurelia species complex. Kappa particles are present in four species of the genus Caedibacter Preer and Preer (18; J. R. Preer, Jr., and L. B. Preer, Int. J. Syst. Bacteriol., in press). The origin of $\mathrm{R}$ bodies is assumed to be a group of defective prophages and extrachromosomal deoxyribonucleic acid (DNA) elements (19). The resistance of the killer paramecia to their own toxin is thought to be due to interac- tions between the extrachromosomal genes of Caedibacter and the nuclear genes of the killer paramecia (18).

Recently, we reported the isolation of a new hydrogen-oxidizing bacterium (strain $2 \mathrm{~K} 1$ ) containing $\mathrm{R}$ bodies $(12,13)$. This free-living bacterium is also infected by a defective phage. More recently, we demonstrated a toxic effect of strain $2 \mathrm{~K} 1$ on susceptible paramecia from stock 152 (11). Thus, the $\mathrm{R}$ bodies of strain $2 \mathrm{~K} 1$ and the Caedibacter $\mathrm{R}$ bodies not only are morphologically similar but also have a similar function.

In this paper we compare the physiological properties of strain $2 \mathrm{~K} 1$ with those of related hydrogen-oxidizing bacteria, as well as with those of the members of the genus Caedibacter. Taxonomically, the results suggest that strain 2K1 represents a new species of the genus Pseudomonas. Further studies of this organism are needed to elucidate the killer function and the interactions between the bacteria and their defective phages, especially at the genetic level.

\section{MATERIALS AND METHODS}

Bacterial strains. Pseudomonas sp. strain $2 \mathrm{~K} 1$ has been described previously $(12,13)$, and a culture of this strain was deposited with the Deutsche Sammlung von Mikroorganismen, Göttingen, Federal Republic of Germany, under the number DSM 2082. Pseudomonas pseudoflava GA3 (= DSM 1034) (2) was used as a reference strain for nutritional characterization, bio- 


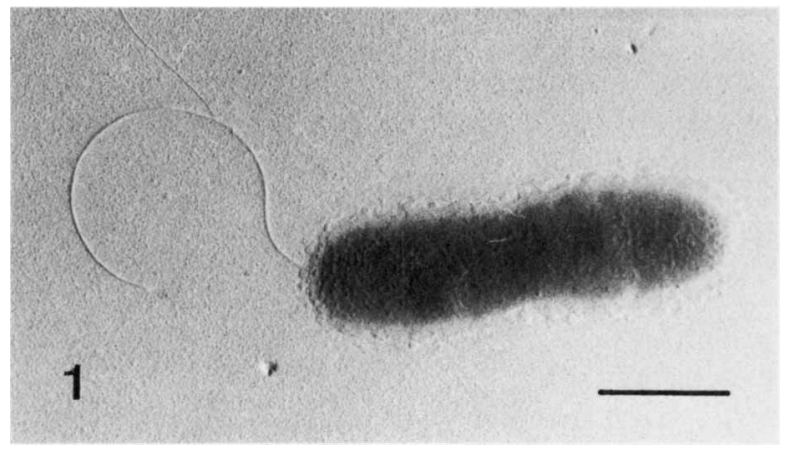

FIG. 1. Cell of strain $2 \mathrm{~K} 1$ from the logarithmic growth phase. Metal shadowed. Bar $=1 \mu \mathrm{m}$ in all figures. (Figures 1 through 3 were made at the Abteilung für Mikromorphologie, Institut für Mikrobiologie, Göttingen, Federal Republic of Germany.)

chemical tests, and DNA studies. Pseudomonas flava DSM 619, Pseudomonas palleronii DSM 63, and Alcaligenes paradoxus DSM 645 were also used as reference strains. Cultures of these strains were obtained from the Deutsche Sammlung von Mikroorganismen.

Methods. Samples were negatively stained with $4 \%$ uranyl acetate $(\mathrm{pH} 4.8)$ or with $1 \%$ phosphotungstic acid ( $\mathrm{pH} \mathrm{7.0)}$ by the technique of Valentine et al. (25) and were observed with a Philips model EM 301 or EM 200 electron microscope. Metal shadowing and ultrathin sectioning were performed as previously described (12).

The basal medium used for growth was the mineral medium described by Schlegel et al. (20). One milliliter of trace elements solution SL6 of Pfennig (17) concentrated 10 -fold was added to $1 \mathrm{ml}$ of medium. The conditions used for autotrophic growth have been described previously (13). For heterotrophic growth, the medium was supplemented with the organic substrate at a final concentration of $1 \%(\mathrm{wt} / \mathrm{vol})$ unless otherwise stated, and the atmosphere was air. In addition, the complete medium contained $0.25 \%$ (wt/ vol) yeast extract, $0.25 \%$ peptone, and $0.25 \%$ sodium succinate. Solid media contained $1.5 \%$ agar (Difco Laboratories). Nutrient broth (Difco) was also used. The incubation temperature was $30^{\circ} \mathrm{C}$.

For growth studies, cells were cultivated in $300-\mathrm{ml}$ Erlenmeyer flasks containing $30 \mathrm{ml}$ of medium with reciprocal shaking ( 80 strokes per $\mathrm{min}$ ) in a Gallenkamp thermocontrolled water bath.

The production of acids from sugars was determined as previously described (3), as was the ability to denitrify (24). Other biochemical features were examined by using the procedures of Cowan (6). The poly$\beta$-hydroxybutyric acid contents of the cells were determined by the method of Law and Slepecki (14). Crude extracts were prepared from autotrophically grown cells harvested in the exponential growth phase. The analysis for cytochromes in the membrane fraction and the soluble fraction at room temperature was also performed as previously described (4). Hydrogenase activity was measured both photometrically and manometrically (21).

Autotrophically grown cells cultured in a Braun Biostat fermentor (13) or cells grown heterotrophically in a Microferm fermentor (New Brunswick Scientific
Co.) were used for determining the gas consumption rates and the hydrogenase activity. The conditions used were those described by Aggag and Schlegel (1).

DNA was isolated, and the guanine-plus-cytosine $(\mathrm{G}+\mathrm{C})$ content of the DNA was determined by the thermal denaturation method of Marmur and Doty (15). DNA-DNA reassociation was performed as previously described (2), and the degree of binding was calculated by using the formula of DeLey et al. (7).

\section{RESULTS}

From soil samples collected near Barcelona, Spain, hydrogen-oxidizing bacteria were isolated after applying the usual enrichment techniques $(1 \mathrm{a}, 9)$ and using the standard medium (20). In the course of morphological studies, strain $2 \mathrm{~K} 1$ aroused attention because it contained spiral bodies. The latter were characterized on the basis of thin-section electron microscopy (12), and their similarities to the $\mathrm{R}$ bodies of kappa particles of paramecia were noted (13).

Exponentially growing cells of strain $2 \mathrm{~K} 1$ are rod shaped, (length, 1 to $3 \mu \mathrm{m}$; width, $0.5 \mu \mathrm{m}$ ) (Fig. 1). In the stationary phase of growth in yeast extract peptone succinate complete medium, filamentous forms (approximately 10 to 15 $\mu \mathrm{m}$ long) and coccoid forms ( 0.3 to $0.5 \mu \mathrm{m}$ in diameter) occasionally appeared (Fig. 2 and 3). Spheres approximately $1 \mu \mathrm{m}$ in diameter resembling spheroplasts also were observed (Fig. 4 and 5); these spheres were stainable with malachite green. The Gram reaction was negative; only the polar regions were slightly stained. The cell wall ultrastructure indicated a typical gramnegative organization (12).

In the early growth phase, the cells were motile by means of a single polarly or subpolarly located flagellum (Fig. 1). In a few cases a flagellum was observed at each pole. The flagella were 3 to $5 \mu \mathrm{m}$ long and 14 to $15 \mathrm{~nm}$ in diameter. Numerous pili 7 to $8 \mathrm{~nm}$ in diameter 


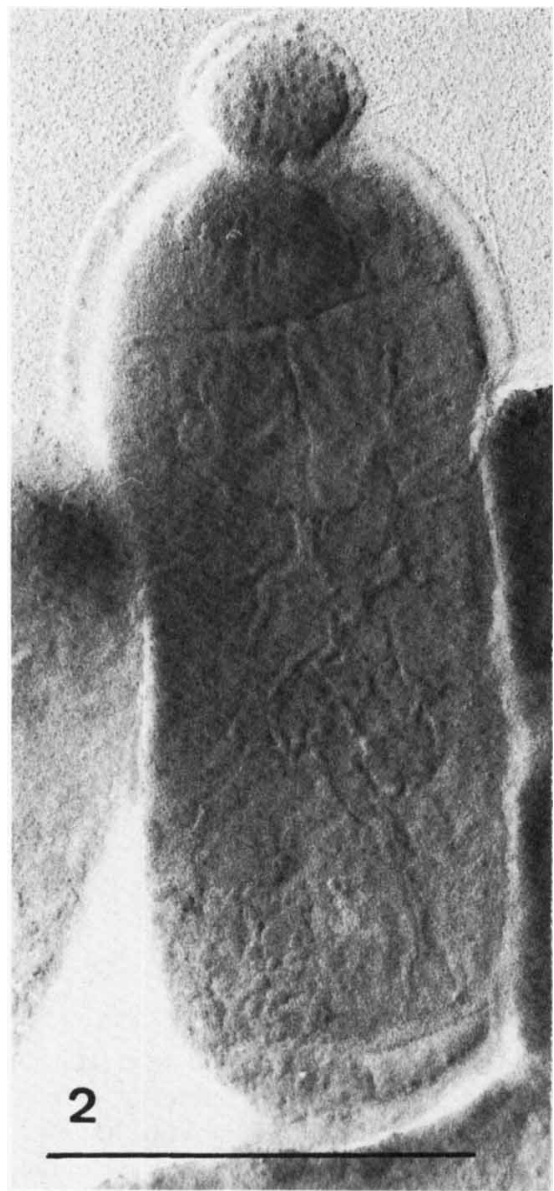

FIG. 2. Coccoid cell protruding from a rod in the stationary growth phase in complete medium. Metal shadowed.

and of varying lengths were observed, primarily in the polar regions (16). Polyphosphate and poly- $\beta$-hydroxybutyric acid granules were easily detected. The colonies were small ( 1 to $2 \mathrm{~mm}$ in diameter under autotrophic conditions and 2 to 3 $\mathrm{mm}$ in diameter under heterotrophic conditions) and yellow, and after 4 days of growth they were characterized by an undulate margin and a convex central elevation.

The biochemical properties of strain $2 \mathrm{~K} 1$ are summarized in Table 1 , and the utilization of various sugars and organic acids as sole carbon sources is presented in Table 2. Among the compounds utilized were nine sugars. Acid was produced under aerobic conditions from several sugars which supported growth. No acid was formed from arabinose, fructose, ribose, or $\mathrm{xy}$ lose. Cytochromes of the $a(600 \mathrm{~nm}), b(562 \mathrm{~nm})$, and $c(550 \mathrm{~nm})$ types were found in the membrane fraction, and cytochromes of the $a$ and $c$ types were found in the soluble fraction of autotrophically grown cells.

The growth rates with organic substrates were higher than the growth rate obtained with hydrogen plus carbon dioxide (Table 3 ). In shaken Erlenmeyer flasks under autotrophic conditions, growth rates of $0.11 \mathrm{~h}^{-1}$ were measured; in a 10liter Braun Biostat fermentor, growth rates of up to $0.17 \mathrm{~h}^{-1}$ were reached. The temperature for optimal growth was $33^{\circ} \mathrm{C}$ under autotrophic conditions and $37^{\circ} \mathrm{C}$ under heterotrophic (sucrose) conditions. Heterotrophic growth occurred up to $40^{\circ} \mathrm{C}$ but not at $42^{\circ} \mathrm{C}$.

Autotrophically grown cells had a specific gas uptake rate of $1,400 \mu \mathrm{l}$ of gas $\left(\mathrm{H}_{2}, \mathrm{O}_{2}\right.$, and $\left.\mathrm{CO}_{2}\right)$ per h per mg of protein; in the absence of $\mathrm{CO}_{2}$ the uptake rate was only $12 \%$ lower $(1,238 \mu$ l of $\mathrm{H}_{2}$ and $\mathrm{O}_{2}$ per $h$ per $\mathrm{mg}$ of protein), indicating the absence of a respiratory control effect (3). With methylene blue as the acceptor, the specific hydrogen uptake rate was $2,340 \mu l$ of $\mathrm{H}_{2}$ per h per $\mathrm{mg}$ of protein. Hydrogenase activity was found only in the membrane fractions of the crude sonic extracts and amounted to $2,824 \mu \mathrm{l}$ of $\mathrm{H}_{2}$ per $\mathrm{h}$ per $\mathrm{mg}$ of protein. No reduction of nicotinamide adenine dinucleotide with $\mathrm{H}_{2}$ could be detected, either in the soluble fractions or in the membrane fractions. Hydrogenase activity was also found in heterotrophically (sucrose or gluconate) grown cells; the hydrogenase activities measured in cells during the logarithmic and stationary growth phases were one-third of the activity of autotrophically grown cells.

The $\mathrm{G}+\mathrm{C}$ content of the DNA of strain $2 \mathrm{~K} 1$ was $60.2 \mathrm{~mol} \%$. The DNA hybridization between strain $2 \mathrm{~K} 1$ and $P$. pseudoflava $\mathrm{GA} 3$ was low; the degree of binding, as calculated from the renaturation rates, was only $45 \%$.

By using electron microscopic inspection of very old, heterotrophically grown cultures (1month incubation) or after treatment with mitomycin C, phage tails and empty phage head-like particles with a diameter of $78 \mathrm{~nm}$ were detected occasionally. The morphologies and dimensions of these particles have been studied previously (13). Complete phage with contracted tails were encountered in only one sample. Suspensions containing these phage like structures did not have a lytic effect either on strain $2 \mathrm{~K} 1$ cells or on related yellow-pigmented hydrogen bacteria (strains of $P$. pseudoflava, $P$. flava, $P$. palleronii, and $A$. paradoxus). Ultraviolet irradiation (13) or a temperature shift $\left(42^{\circ} \mathrm{C}\right.$ for $\left.30 \mathrm{~min}\right) \mathrm{did}$ not induce phage like structures or phage formation.

\section{DISCUSSION}

The morphological and physiological properties of strain $2 \mathrm{~K} 1$ fit the description of the genus 


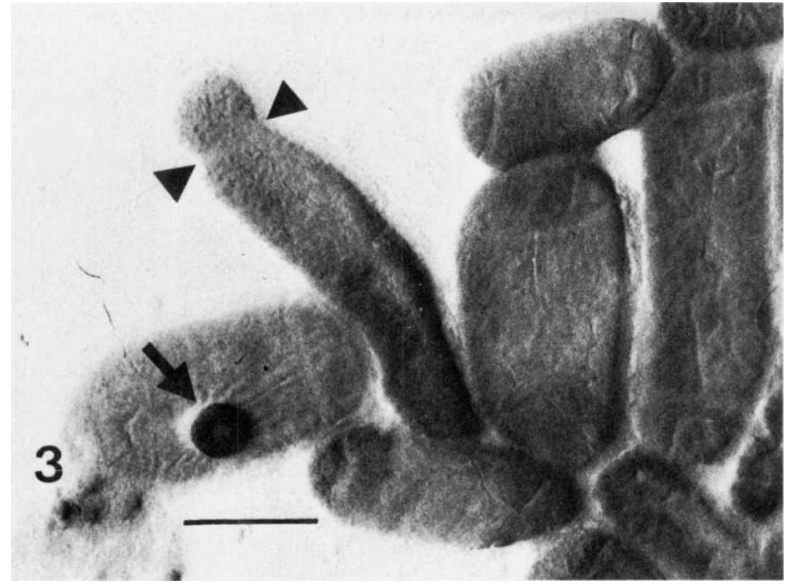

FIG. 3. Coccoid cell like that in Fig. 2 (arrowheads) and cell showing an R body (arrow) with a ring structure. Metal shadowed.
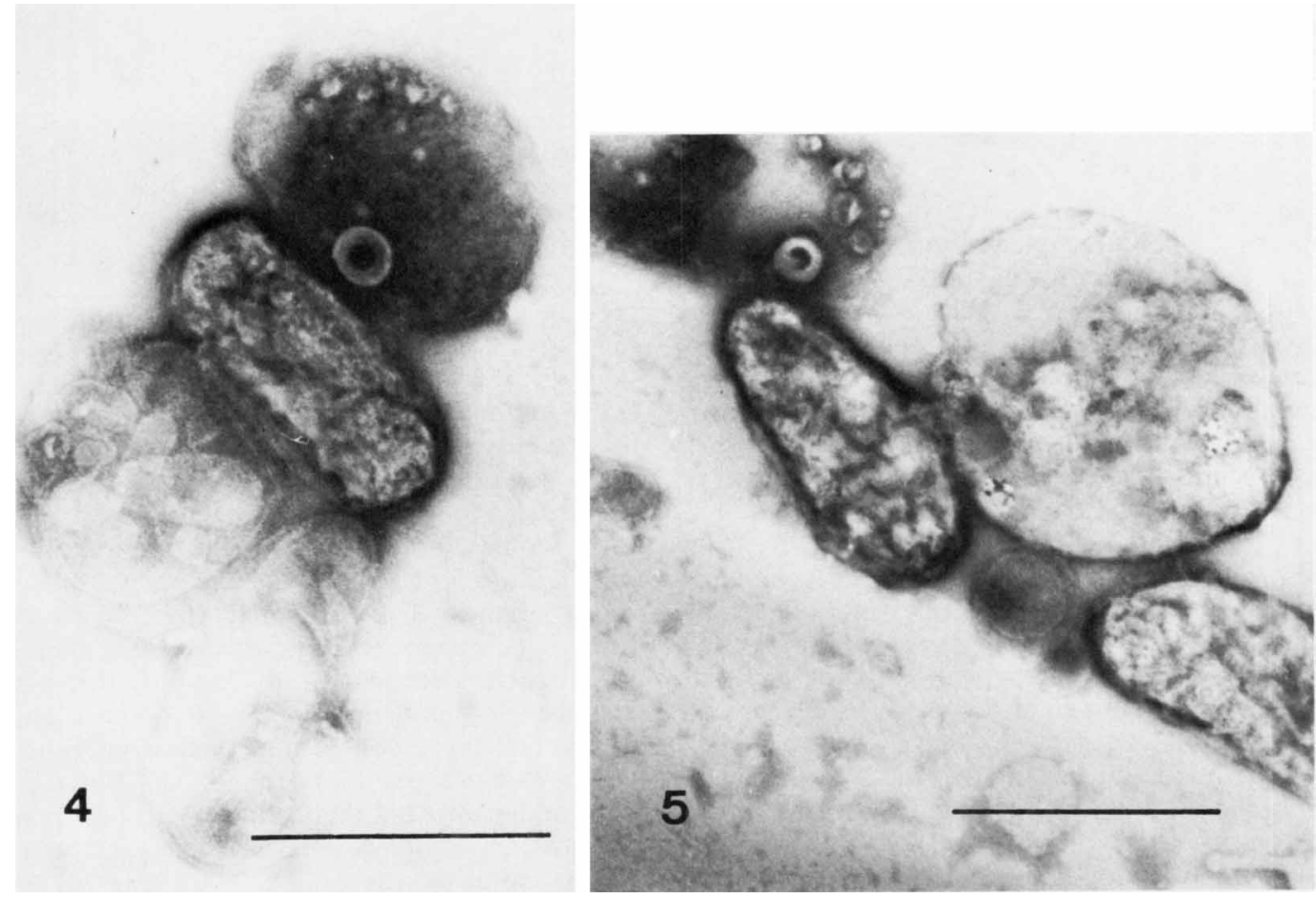

FIG. 4 and 5. Autotrophically grown cells in the stationary growth phase with and without $\mathrm{R}$ bodies. resembling spheroplasts. Negatively stained. (Prepared at the Servicio de Microscopía Electrónica, Universidad de Barcelona, Barcelona, Spain.)

Pseudomonas given in Bergey's Manual of Determinative Bacteriology, 8th ed. (8). This organism is a gram-negative rod-shaped bacterium, is motile by means of a single polar flagellum, has exclusively respiratory metabolism, forms no spores, and is oxidase and catalase positive. With a $\mathrm{G}+\mathrm{C}$ content of $60 \mathrm{~mol} \%$, it is well differentiated from other yellow-pigmented, polarly flagellated, mesophilic, hydrogen-oxidizing bacteria, such as $P$. pseudoflava $(\mathrm{G}+\mathrm{C}$ content, 66.5 to $68 \mathrm{~mol} \%)$, P. flava (67.3 mol\%), Pseudomonas hydrogenovora $(62.5 \mathrm{~mol} \%)$, and $P$. palleronii $(66.8 \mathrm{~mol} \%)$.

Strain $2 \mathrm{~K} 1$ has in common with $P$. pseudo- 
TABLE 1. Biochemical characteristics of strain $2 \mathrm{~K} 1$

\begin{tabular}{|c|c|}
\hline Test & Result \\
\hline Aerobic autotrophic growth with $\mathrm{H}_{2} \ldots \ldots \ldots$ & + \\
\hline Aerobic autotrophic growth with $\mathrm{CO} \ldots \ldots$ & - \\
\hline Utilization of nitrate as nitrogen source ...... & + \\
\hline Utilization of dinitrogen . . . . . . . . . . . & - \\
\hline Heterotrophic denitrification ............ & + \\
\hline Autotrophic denitrification .............. & - \\
\hline 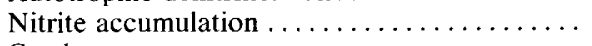 & + \\
\hline Catalase..$\ldots \ldots \ldots \ldots \ldots \ldots \ldots \ldots \ldots \ldots \ldots \ldots \ldots$ & + \\
\hline Oxidase $\ldots \ldots \ldots \ldots \ldots \ldots$ & + \\
\hline Urease $\ldots \ldots \ldots \ldots \ldots \ldots \ldots \ldots \ldots \ldots \ldots \ldots$ & - \\
\hline 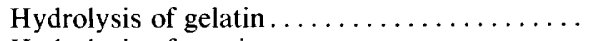 & + \\
\hline Hydrolysis of casein ... & - \\
\hline Hydrolysis of starch. & - \\
\hline Hydrolysis of esculin $\ldots \ldots \ldots \ldots \ldots \ldots$ & - \\
\hline Hydrolysis of poly- $\beta$-hydroxybutyric acid .... & - \\
\hline Hydrolysis of DNA (thymus) $\ldots \ldots \ldots \ldots \ldots$ & - \\
\hline Production of fluorescent water-soluble pigment & - \\
\hline Production of indole $\ldots \ldots \ldots \ldots \ldots \ldots$ & - \\
\hline Production of $\mathrm{H}_{2} \mathrm{~S}$ from cysteine $\ldots \ldots \ldots \ldots$ & - \\
\hline Production of gas from glucose or lactose .... & - \\
\hline Production of acetoin $\ldots \ldots \ldots \ldots \ldots \ldots$ & - \\
\hline Production of acids from carbohydrates..... & - \\
\hline \multicolumn{2}{|l|}{ Storage materials } \\
\hline Poly- $\beta$-hydroxybutyric acid & + \\
\hline Polyphosphates........... & + \\
\hline
\end{tabular}

flava the essential characteristics of this species, namely, facultative chemolithoautotrophy, utilization of a wide range of sugars, yellow pigmentation, heterotrophic denitrification, tolerance to $20 \%(\mathrm{vol} / \mathrm{vol})$ oxygen, and an optimum temperature of $37^{\circ} \mathrm{C}$. These characteristics exclude any relationship of strain $2 \mathrm{~K} 1$ to strains of the known species of the genus Pseudomonas and to other hydrogen-oxidizing bacteria $(1 \mathrm{a}, 2,5)$ and indicate a close relationship to $P$. pseudoflava.

However, strain $2 \mathrm{~K} 1$ differs remarkably from $P$. pseudoflava strains in some biochemical characteristics, by the presence of $\mathrm{R}$ bodies, and by a tendency to pleomorphism. In strain $2 \mathrm{~K} 1$ pleomorphism can be explained by the fact that the organism carries a defective prophage and can produce nonviable phage like particles, whose induction promotes the formation of spheroplast-like structures and, probably, of filamentous forms. The latter occur abundantly after treatment by ultraviolet irradiation; 5 to 10 $\mathrm{R}$ bodies are formed per filament (13). The spheroplast-like forms are probably cells lysed by phage induction, and in most cases they contain $\mathrm{R}$ bodies. The coccoid forms resemble the minicells produced by other bacteria in which plasmids have been detected (10). The 45\% DNA-DNA homology between strain $2 \mathrm{~K} 1$ and $P$. pseudoflava GA3 excludes a close taxonomic relationship between these strains, although the difference in $\mathrm{G}+\mathrm{C}$ content is low (7 mol\%). Only Pseudomonas sp. strain GA6, which has moderate homology $(61 \%)$ to strain
TABLE 2. Sole carbon source utilization by strain $2 \mathrm{~K} 1$

\begin{tabular}{|c|c|}
\hline Sole carbon source ${ }^{a}$ & Utilization \\
\hline \multicolumn{2}{|l|}{ Sugar } \\
\hline 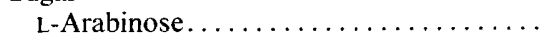 & + \\
\hline D-Fructose $\ldots \ldots \ldots \ldots \ldots \ldots \ldots$ & + \\
\hline D-Galactose $\ldots \ldots \ldots \ldots \ldots \ldots \ldots$ & + \\
\hline D-Glucose $\ldots \ldots \ldots \ldots \ldots \ldots \ldots \ldots$ & + \\
\hline Maltose $\ldots \ldots \ldots \ldots \ldots \ldots \ldots \ldots$ & - \\
\hline D-Mannose $\ldots \ldots \ldots \ldots \ldots \ldots \ldots$ & + \\
\hline L-Rhamnose $\ldots \ldots \ldots \ldots \ldots \ldots \ldots \ldots$ & + \\
\hline D-Ribose $\ldots \ldots \ldots \ldots \ldots \ldots \ldots \ldots$ & - \\
\hline D-Sorbose $\ldots \ldots \ldots \ldots \ldots \ldots \ldots$ & - \\
\hline Sucrose $\ldots \ldots \ldots \ldots \ldots \ldots \ldots$ & + \\
\hline Trehalose ................... & + \\
\hline D-Xylose $\ldots \ldots \ldots \ldots \ldots \ldots \ldots$ & + \\
\hline \multicolumn{2}{|l|}{ Organic acid } \\
\hline 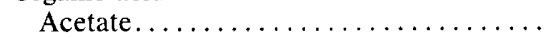 & - \\
\hline Benzoate . . . . . . . . . . . . . . & - \\
\hline 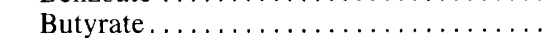 & - \\
\hline Citrate $\ldots \ldots \ldots \ldots \ldots \ldots \ldots \ldots \ldots \ldots \ldots \ldots$ & - \\
\hline Formate $\ldots \ldots \ldots \ldots \ldots \ldots \ldots$ & + \\
\hline Fumarate $\ldots \ldots \ldots \ldots \ldots \ldots \ldots$ & + \\
\hline Gluconate $\ldots \ldots \ldots \ldots \ldots \ldots \ldots$ & + \\
\hline 4-Hydroxybenzoate $\ldots \ldots \ldots \ldots \ldots$ & - \\
\hline L-Isoleucine $\ldots \ldots \ldots \ldots \ldots \ldots \ldots$ & + \\
\hline DL-Lactate . . . . . . . . . . . . . . & + \\
\hline L-Lysine $\ldots \ldots \ldots \ldots \ldots \ldots \ldots$ & + \\
\hline Malonate $\ldots \ldots \ldots \ldots \ldots \ldots \ldots$ & - \\
\hline Mesaconate $\ldots \ldots \ldots \ldots \ldots \ldots$ & - \\
\hline Pyruvate............... & + \\
\hline L-Tyrosine $\ldots \ldots \ldots \ldots \ldots \ldots \ldots$ & + \\
\hline
\end{tabular}

${ }^{a}$ With ammonium as the nitrogen source.

GA3 (2), could be related to strain $2 \mathrm{~K} 1$, but the culture of strain GA6 has been lost.

The genus Caedibacter comprises all R-bodycontaining bacteria that are obligately endosymbiotic with Paramecium biaurelia and Paramecium tetraurelia (19). The $\mathrm{G}+\mathrm{C}$ contents of the DNAs of these bacteria range from 40 to 44 mol\%. The members of the genus Caedibacter and free-living strain $2 \mathrm{~K} 1$ are the only bacteria described so far which contain $\mathrm{R}$ bodies. The presence of these conspicuous inclusion bodies suggests a close taxonomic relationship between these organisms, but their physiological properties and $\mathbf{G}+\mathrm{C}$ contents differ so significantly that any taxonomic relationship can be excluded. As suggested by Preer et al. (18), the R bodies of Caedibacter may be coded by defective phages or plasmids. The presence of defective phages in strain $2 \mathrm{~K} 1$ adds another argument in favor of this assumption and supports the hypothesis that the strain $2 \mathrm{~K} 1 \mathrm{R}$ bodies are due to the presence of phages of the same type as the phages in Caedibacter. Therefore, we conclude that strain 2K1 belongs to the genus Pseudomonas and represents a new species of yellow-pigmented, hydrogen-oxidizing bacteria. Because of its possession of $\mathrm{R}$ bodies and its close similarity to the 
TABLE 3. Growth rates of strain $2 \mathrm{~K} 1$ with different substrates as measured in $300-\mathrm{ml}$ shaken Erlenmeyer flasks containing $30 \mathrm{ml}$ of medium at $30^{\circ} \mathrm{C}$

\begin{tabular}{|c|c|}
\hline Substrate & Growth rate $\left(\mathrm{h}^{-1}\right)^{a}$ \\
\hline Sucrose $\ldots \ldots \ldots \ldots \ldots \ldots \ldots$ & 0.32 \\
\hline Glucose $\ldots \ldots \ldots \ldots \ldots \ldots \ldots$ & 0.29 \\
\hline Nutrient broth.............. & 0.28 \\
\hline Gluconate $\ldots \ldots \ldots \ldots \ldots \ldots$ & 0.26 \\
\hline Glutamate $\ldots \ldots \ldots \ldots \ldots \ldots \ldots$ & 0.24 \\
\hline Fructose......... & 0.24 \\
\hline Galactose................. & 0.17 \\
\hline Lactate $\ldots \ldots \ldots \ldots \ldots \ldots \ldots$ & 0.17 \\
\hline Pyruvate................. & 0.13 \\
\hline Hydrogen + carbon dioxide $\ldots . .$. & 0.11 \\
\hline
\end{tabular}

${ }^{a}$ The growth rates were calculated on the basis of half-logarithmic plots of optical density at $436 \mathrm{~nm}$ versus time.

obligately endosymbiotic bacterium Caedibacter taeniospiralis, the name Pseudomonas taeniospiralis is proposed for this new species, a description of which follows.

Pseudomonas taeniospiralis sp. nov. (tae.ni.o.spi.ra'lis. Gr. noun taenia ribbon; L. adj. spiralis coiled; M.L. adj. taeniospiralis ribbon coiled; named after Caedibacter taeniospiralis, an organism with which it has characters in common). Rod-shaped cells 0.5 by 1.0 to 3.0 $\mu \mathrm{m}$, with a tendency to pleomorphism. Gram negative. Motile by means of a single polar or subpolar flagellum. Variable proportions of cells in the stationary growth phase contain typical characteristic inclusions referred to as $\mathrm{R}$ bodies; these are convoluted, proteinaceous ribbons. The $\mathrm{R}$ bodies have an average diameter of 0.25 $\mu \mathrm{m}$ and an average height of $0.21 \mu \mathrm{m}$. Poly- $\beta-$ hydroxybutyric acid and polyphosphate inclusions are present. Colonies are yellow.

Temperature for optimal growth: $37^{\circ} \mathrm{C}$. Either chemolithoautotrophic, using $\mathrm{H}_{2}$ as the electron donor and $\mathrm{CO}_{2}$ as the carbon source, or chemoorganoheterotrophic; strictly respiratory in metabolism, with oxygen as the terminal electron acceptor, or (only heterotrophically) with denitrification of nitrate. The hydrogenase is membrane bound and is not nicotinamide adenine dinucleotide specific. $\mathrm{CO}_{2}$ is fixed autotrophically via the ribulose bisphosphate cycle. Among the hydrogen-oxidizing bacteria, this organism is outstanding because of its ability to utilize nine sugars; many organic acids and amino acids are also used. Catalase and oxidase are produced. Gelatin is hydrolyzed, but casein, starch, esculin, and poly- $\beta$-hydroxybutyric acid are not hydrolyzed.

Exerts a toxic effect against strains of paramecia.

Source: isolated from a soil sample collected near Barcelona, Spain.

Strain $2 \mathrm{~K} 1$ is designated as the type strain for the species. A culture of this strain has been deposited with the Deutsche Sammlung von Mikroorganismen under the number DSM 2082. The description of the type strain is the same as that given above for the species, with the following addition: the $\mathrm{G}+\mathrm{C}$ content of the DNA is $60.2 \mathrm{~mol} \%$.

\section{ACKNOWLEDGMENTS}

We are grateful to $M$. Reh and $M$. Dürre for the DNA analyses, to I. Probst for the determination of cytochromes, to $\mathrm{R}$. Brinkmann for autotrophic fermentor cultures, and to $\mathrm{O}$. Meyer for examining the utilization of carbon monoxide. We thank F. Mayer, H. Lünsdorf, W. Johannssen, R. Bargalló, and J. López for help with the electron microscopy studies.

J. L. was supported in part by an award from the Alexander von Humboldt Foundation, Bonn, Federal Republic of Germany.

\section{REPRINT REQUESTS}

Address reprint requests to: Dr. J. Lalucat, Departamento de Microbiología, Facultad de Ciencias, Crtr. Valldemossa $\mathrm{Km}$ 7.5. Palma de Mallorca, Spain.

\section{LITERATURE CITED}

1. Aggag, M., and H. G. Schlegel. 1973. Studies on a grampositive hydrogen bacterium, Nocardia opaca strain $1 \mathrm{~b}$. Arch. Microbiol. 88:299-318.

1a.Aragno, M., and H. G. Schlegel. 1981. The hydrogenoxidizing bacteria, p. 865-893. In M. P. Starr, H. Stolp, H. G. Trüper, A. Balows, and H. G. Schlegel (ed.), The prokaryotes. A handbook on habitats, isolation and identification of bacteria. Springer-Verlag, Berlin.

2. Auling, G., M. Reh, C. M. Lee, and H. G. Schlegel. 1978. Pseudomonas pseudoflava, a new species of hydrogenoxidizing bacteria: its differentiation from Pseudomonas flava and other yellow-pigmented, gram-negative, hydrogen-oxidizing species. Int. J. Syst. Bacteriol. 28:82-95.

3. Bartha, R. 1962. Physiologische Untersuchungen über den chemolithotrophen Stoffwechsel neu isolierter $\mathrm{Hydro-}$ genomonas-Stämme. Arch. Mikrobiol. 41:313-350.

4. Bernard, U., I. Probst, and H. G. Schlegel. 1974. The cytochromes of some hydrogen bacteria. Arch. Microbiol. 95:29-37.

5. Bowien, B., and H. G. Schlegel. 1981. Physiology and biochemistry of aerobic hydrogen-oxidizing bacteria. Annu. Rev. Microbiol. 35:405-452.

6. Cowan, S. T. 1974. Cowan and Steel's manual for the identification of medical bacteria, 2 nd ed. Cambridge University Press, New York.

7. DeLey, J., H. Cattoir, and A. Reynaerts. 1970. The quantitative measurement of DNA-hybridization from renaturation rates. Eur. J. Biochem. 12:133-142.

8. Doudoroff, M., and N. J. Palleroni. 1974. Genus Pseudomonas, p. 217-253. In R. E. Buchanan and N. E. Gibbons (ed.), Bergey's manual of determinative bacteriology, $8 \mathrm{th}$ ed. The Williams \& Wilkins Co., Baltimore.

9. Eberhardt, U. 1965. Die Anreicherung von Knallgasbakterien, p. 155-169. In H. G. Schlegel and E. Kröger (ed.), Anreicherungskultur und Mutantenauslese. G. Fischer Verlag, Stuttgart.

10. Frazer, A. C., and R. Curtis III. 1975. Production, properties and utility of bacterial minicells. Curr. Top. Microbiol. Immunol. 69:1-84

11. Lalucat, J., A. Alvarez, R. Parés, and H. G. Schlegel. 1980. R bodies in Pseudomonas, p. 409-416. In W. Schwemmler and H. E. A. Schenk (ed.), Endocytobiology, endosymbiosis and cell biology. Walter de Gruyter, Berlin.

12. Lalucat, J., and F. Mayer. 1978. "Spiral-bodies" - intracytoplasmic membraneous structures in a hydrogen-oxidizing bacterium. Z. Allg. Mikrobiol. 18:422-427.

13. Lalucat, J., O. Meyer, F. Mayer, R. Parés, and H. G. 
Schlegel. 1979. R-bodies in newly isolated free-living hydrogen-oxidizing bacteria. Arch. Microbiol. 121:9-15.

14. Law, J. H., and R. A. Slepecki. 1961. Assay of polyhydroxybutyric acid. J. Bacteriol. 82:33-36.

15. Marmur, J., and P. Doty. 1962. Determination of the base composition of deoxyribonucleic acid from its thermal denaturation temperature. J. Mol. Biol. 5:109-118.

16. Mayer, F. 1979. Elektronenmikroskopische Beobachtungen zur Insertion der Pili bei dem neuisolierten wasserstoffoxidierenden Bakterium 2K1. Z. Allg. Mikrobiol. 19:123-127.

17. Pfennig, N. 1974. Rhodopseudomonas globiformis, sp. n., a new species of the Rhodospirillaceae. Arch. Microbiol. 100:197-206.

18. Preer, J. R., Jr., L. B. Preer, and A. Jurand. 1974. Kappa and other endosymbionts in Paramecium aurelia. Bacteriol. Rev. 38:113-163.

19. Quackenbush, R. L. 1978. Genetic relationship among bacterial endosymbionts of $P$. aurelia: deoxyribonucleotide sequence relationships among members of Caedi- bacter. J. Gen. Microbiol. 108:181-187.

20. Schlegel, H. G., H. Kaltwasser, and G. Gottschalk. 1961. Ein Submersverfahren zur Kultur wasserstoffoxidierender Bakterien: wachstumsphysiologische Untersuchungen. Arch. Microbiol. 38:209-222.

21. Schneider, K., and H. G. Schlegel. 1977. Localization and stability of hydrogenases from aerobic hydrogen bacteria. Arch. Microbiol. 112:229-238.

22. Soldo, A. T. 1974. Intracellular particles in Paramecium aurelia, p. 375-442. In W. van Wagtendonk (ed.), Paramecium: a current survey. Elsevier Press, Amsterdam.

23. Sonneborn, T. M. 1959. Kappa and related particles in Paramecium. Adv. Virus Res. 6:229-356.

24. Stanier, R. Y., N. J. Palleroni, and M. Doudoroff. 1966. The aerobic pseudomonads: a taxonomic study. J. Gen. Microbiol. 43:159-271.

25. Valentine, R. C., B. M. Shapiro, and E. R. Stadtman. 1968. Regulation of glutamine synthetase. XII. Electron microscopy of the enzyme from E. coli. Biochemistry 7:2143-2152. 